МЕНЕДЖМЕНТ

UDC 338.2:37.06

\author{
I. M. Gryshchenko, Doctor of Economic \\ Sciences, Professor, \\ O. Y. Chubukova, Doctor of Economic \\ Sciences, Professor
}

\section{INFORMATION CULTURE AS THE BASIS FOR EFFICIENT TALENT MANAGEMENT}

Urgency of the research. At the present stage of social development, the importance of studying the foundations of information culture formation is entailed by the search for new mechanisms for improving the professional and personal qualities of an individual.

Target setting. It is expedient to define the essence of the category "talent" as a factor of social development and methodological approaches to the talent management in the framework of the modern information paradigm of socioeconomic development.

Analysis of recent researches and publications. The research results on the society current state, its transformational processes and requirements to the person as the basis of social development have been presented in scientific works of foreign and domestic scientists, such as Gardner G., Michael A., Shweyer A., Molyako V., Reznikov Zh. I. and others, present

Uninvestigated parts of general matters defining. The scientists have not yet sufficiently researched the issues of the talent essence in management, the talent importance of social interaction as a factor of scientific and technological progress and their influence on the information culture formation.

The research objective. The article is aimed at studying the social interaction talent as one of the main qualities for a man of today, issues of talent management and how information and information culture influence its development

The statement of basic materials. The concepts "talent", "talent management", "information culture" have been investigated in the article. Their absolute interrelation and influence on personality formation, organization development, team activity and their effectiveness are proved. The possible ways of talent and personality cultivating in the conditions of innovative development society, the widespread introduction of information and telecommunication technologies are highlighted.

Conclusions. Talent management on the basis of highlevel information culture in combination with information and communication technologies enables to formulate effectively processes of managing and functioning of any organization. Thus, the basis of the social development of the third millennium are the conditions for the effective realization of human talent, not only in the personal perspective, but also in the framework of social interaction based on the information culture mastery, without which further progress of the work intellectual tools and new information technologies is impossible.

Keywords: social interaction talent; talent management; information culture; information and telecommunication technologies.
УДК 338.2:37.06

\author{
І. М. Грищенко, д. е. Н., \\ професор, \\ О. Ю. Чубукова, д. е. Н., \\ професор
}

\section{ІНФОРМАЦІЙНА КУЛЬТУРА ЯК ОСНОВА ЕФЕКТИВНОГО УПРАВЛІННЯ ТАЛАНТОМ}

Актуальність теми дослідження. Важливість вивчення засад формування інформаційної культури на сучасному етапі суспільного розвитку викликана пошуком нових механізмів вдосконалення професійних та особистісних якостей людини.

Постановка проблеми. Доцільним $\epsilon$ визначення сутності категорії «талант» як фактору суспільного розвитку та методологічних підходів до управління талантом в рамках сучасної інфрормаційної парадигми соціоекономічного розвитку.

Аналіз останніх досліджень $і$ публікацій. В наукових працях зарубіжних і вітчизняних вчених, таких як Гарднер Г., Майклз Е., Швейєр А., Моляко В.О. Рєзнікова Ж. І. та інших, викладено результати досліджень щодо сучасного стану суспільства, його трансформаційних процесів та вимог до людини як основи суспільного розвитку.

Виділення недосліджених частин загальної проблеми. Науковцями ще недостатньо опрацьовані питання сутності таланту у менеджменті, важливості таланту суспільної взаємодії як фрактору науково-технічного прогресу та впливу інфоормаційноі культури на його формування.

Постановка завдання. Стаття спрямована на вивчення таланту соціальної взаємодії як однієї 3 основних якостей сучасної людини, питань управління талантом та впливу на його розвиток інфрормації та інфоормаційної культури.

Виклад основного матеріалу. У статmі досліджені поняття «талант», «управління талантом», «інформаційна культура». Доведено їх безумовний взаємозв'язок і вплив на формування особистості, розвиток організації, командної діяльності та їх ефективності. Висвітлено можливі шляхи плекання таланту й особистості в умовах суспільства інноваційного розвитку, повсюдного впровадження інфоормаційно-телекомунікаційних технологій.

Висновки. Управління талантом на основі інфрормаційної культури високого рівня в поєднанні з інформаційно-комунікаційними технологіями дає можливість ефрективно фоормувати процеси управління та функціонування будь-яких організацій. Таким чином, в основі суспільного розвитку третього тисячоліття лежать умови ефективної реалізації таланту людини не тільки в особистому ракурсі, але й у рамках суспільної взаємодії, що базуються на опануванні інформаційної культури, без якої стає неможливим подальщий прогрес інтелектуальних знарядь праці й нових інформаційних технологій.

Ключові слова: талант суспільної взаємодії; управління талантом; інфрормаційна культура; інфрормаційно-телекомунікаційні технології. 


\section{МЕНЕДЖМЕНТ}

DOI: $10.25140 / 2410-9576-2017-2-4(12)-100-105$

Urgency of the research. Nowadays, information changes and the results of scientific and technological progress have the greatest influence on the society development throughout a hundred years. After all, thanks to them humanity has already reached the stage of Industry 4.0. However, despite all the information, technical, cultural, economic achievements there should not be forgotten about the true creator of social progress - an individual with all his qualitative characteristics. This individual is always at the forefront in any period of social progress.

Target setting. Changing the world, people change demands for themselves. And now, more than ever, the attention is paid to the components of human existence: knowledge level, information culture, social interaction talent and management.

Analysis of recent researches and publications. The scholarly writings of Gardner $G$., Michael A., Schweijer A., Molyako V., Reznikov Zh. and others are devoted to the research of the new type society peculiarities and a personality in it.

Uninvestigated parts of general matters defining. Analyzing modern processes of social development of a new generation, scholars often use the notion "talent", mostly interpreted from the point of art view (talent for singing, dancing, painting, literature learning, etc.) as a qualitative personality trait. However, they almost do not explore the category "talent" in management as a professional personality trait of the manager who forms the ability to take effective managerial decisions and team up in teamwork, and talent as the ability to work in a team, that is talent towards social interaction. The phenomenon of talent in relation to the development of science and technology, modern progress and the development of society has not been researched at all.

The research objective. The purpose of this article is to research the social interaction talent as one of the main qualities of a man of today, issues of talent management and influence of information and information culture on its development.

The statement of basic materials. Every person is born with his own certain qualities, abilities and talents. The environment, family, knowledge level, culture, etc influence the fact how these qualities will be developed used throughout life.

The quality of a person, whose development depends, to a large extent, on social influences, is talent, that is the natural giftedness and ability of a person, ability to a particular type of activity that enables successful, independent and original performance of any complex work.

In modern business, the key role is played by people who work on the outcome [2]. Therefore, there is nothing more successful than managing them effectively and developing their talents. In this aspect, involving professionals is a comprehensive talent management strategy that involves attracting, developing and retaining talented employees.

There are certain types of talent that people have. The famous scientist Howard Gardner in his book "The Structure of the Mind". The theory of multiple intelligence "states that a person can possess not only the general (sole) talent, but a number of relatively independent abilities. He distinguished seven types of talent, intelligence (linguistic, musical, logical and mathematical, spatial, physical, interpersonal, interindividual) and of its eight "signs" [1], namely:

- a potential isolation as a result of cerebral trauma, which can activate previously unknown talents and skills;

- a presence of the mentally retarded, the prodigies and other unusual individuals, when one of individual abilities is kept in unique purity against the background of slowed down performance in various spheres;

- a noticeable set of basic operations, for example, the height of the sound showing musical talent, or the ability to simulate movement as the main skill of the corporeal intelligence;

- a personal history of development and different from other set of "final" characteristics;

- evolutionary history and evolutionary plasticity;

- support from experimental psychology;

- support from psychometrics;

- susceptibility to decoding symbolic systems. 


\section{МЕНЕДЖМЕНТ}

However, only possession of a certain talent does not solve the problem of human living in society and the creation of new benefits. Talent needs to be developed and controlled. The talent is developed due to raising knowledge level and education, changes in the environment. Talent management in the opinion of many scholars and practitioners is the activity in the field of personnel management, which is aimed at attracting employees into innovative processes, creating incentives, motivating measures, developing creative potential of employees. Talent management is the creation and development of a creative team through a combination of human resources and the effectiveness of the organizational structure.

For the first time, the term "talent management" was used in the late 90's of the last century in the US in the research of labor markets and production optimization. The definition was interpreted as a set of human resources management tools that made it possible to attract, use and retain employees who form the basis for effective organization development [10].

It should be noted, that the science and technology achievements, automation and computerization of all production and management processes, the introduction of information and telecommunication technologies have radically changed the man attitude towards participation in business, as well as the possibility of obtaining moral and financial rewards. That is, the work with information led to the need of creation and mastering the information culture, which has recently become an integral part of human culture.

Information is one of the main resources of development. It is involved in socio-political and economic processes so deep, that there is rethinking of the essence of the individual not only against the backdrop of global information flows, but also in the rivalry with them.

Information as a manifestation of material culture has no boundaries, it destroys the barriers between peoples and countries, freely distributes among users through its exchange, affects the state and development of all spheres of the world economy.

Society informatization of is an objective regularity of modern social development. The transition to the information society, in particular, to the society of innovation development and knowledge, requires from the person as an information carrier and user appropriate training, acquiring certain aspirations, qualities and knowledge for the rapid perception and processing of large data sets, the ability to respond to rapid changes in quality and technical characteristics of computers, software, modern methods, tools and technologies. In addition, new requirements and working conditions generate the dependence of one person awareness from another person awareness. Therefore, it becomes inadequate to be able to independently master and accumulate information. It is necessary to develop the ability to work in a team, to learn such technology of work with information, when decisions are prepared and accepted based on collective knowledge. This means that every person, every employee must have a certain level of information culture.

Culture, of course, belongs to the most complex and multi-faceted phenomena; therefore, it is not always understood unambiguously. It manifests itself as an important component of human activity (technological culture, environmental, artistic, culture of thinking and feelings, labor and customs, etc.). Information culture is correlated with the whole set of information processes that a person uses in his life and talent management. The person collects knowledge of those sciences that contribute to his development and adaptation to a particular type of activity.

An integral part of information culture is the knowledge of new information technologies, the ability to use them for computerization of managerial, economic, technological and production processes, and in extraordinary situations that require non-traditional solutions, and most importantly - in people collective communication.

At the present stage of social development, information culture, personality, talent and society are investigated as a special aspect of human culture in general. It means the integral designation of those aspects of culture, that directly reflect the entire set of information processes, which a person uses in his life.

The main feature of information culture, its main source, which ensures the life confidence and welfare, is a highly effective economic activity of all society members. It becomes both a condition and a sign of a civilized economic organization based on means of production that consists of intellectual 


\section{МЕНЕДЖМЕНТ}

tools and new information technologies. It also provides the highest, in terms of world standards, level of labor productivity and production efficiency, creation of a large number and assortment of goods and services, which ultimately is a prerequisite for happy and comfortable life, effective talent management, progressive society development.

Information culture puts a fair amount of demands on all users of intellectual tools (human rights enhancers - computers, software, creation of new knowledge and skills, etc.). These requirements vary according to their origin and character, in some cases they acquire a moral sense, others require legal, technical, etc. However, all these rules or requirements are conditioned by the principles and norms of morality, law, and mutual respect [5].

The basic principles of information culture are worth considering:

1. An integrated approach to solve information problems of management. This principle excludes the solution of issues related to the improvement of the production management system on the basis of a particular science, for example, economics, sociology, cybernetics, etc. The business entity is a rather complicated mechanism, which combines different aspects of production: technical (equipment, technology, machinery), economic (forms of self-financing, system of material incentives, etc.); organizational (forms and methods of production management, organization of labor); human and socio-psychological (labor collective, conflict situations, working conditions, tension, tiredness, desire to raise the level of knowledge, intelligence, talent, etc.). Therefore, solving the problem of managing a complex mechanism, in particular talent, needs an integrated approach based on the use of various scientific disciplines.

2. General organization of information systems. When creating and functioning integrated management systems at socio-economic objects, it is necessary to organize the system's components: technologies, processes of management, information structures, management methods and obligations of officials.

3. Philosophy, determined by the relationship between developers and customers.

4. Searching for characteristics of people's behavior that are constantly repeated, their interaction, rituals, forms of manifestation, rules of conduct.

5. Respect for the individual rights, encouraging the free exchange of information.

6. Game rules which must be abided to achieve and maintain the success of the business, normal relationships in the team, the image at the market.

7. Security and protection of information in telecommunication networks.

The principles of information culture are interconnected, so unilateral improvement of one of them does not provide the expected effect and cannot justify costs. At the same time, the following requirements for the development of each principle are defined, determining its place and role in the system, the nature and content of its relationship with other principles. At the same time, the following requirements for the development of each principle determine its place and role in the system, the nature and content of its interrelationship with other principles.

Due to the elements of information culture there are opportunities to raise the knowledge level, intelligence, improve talents and the quality of management, simplify the processes of management, improve working conditions, expanding motivational measures, improve the skills of work in the team. This ensures a more exact and balanced work of the personnel, raises state and labor discipline, efficiency of talent management and personal development.

It should be emphasized, that nowadays there can be found no definition to characterize the state of a business entity or individual, besides the notion of "information culture", since it is the expression and manifestation of reasonableness, rationality of organization and management of the production process, the development of the individual, where each component is clearly regulated and balanced.

There should be understood that the level of information culture cannot be expressed in specific units of measurement (tons of production, hryvnya savings, percentages, etc.). However, productivity, profitability, product quality, knowledge level and aspirations are all indicators of information culture, which are directly dependent on its availability / absence. Information culture itself is a generator of deep socio-economic transformations, improvement of qualitative characteristics of an individual, his 


\section{МЕНЕДЖМЕНТ}

talent and intelligence. Information culture allows us to get answers to many questions related to the formulation and solution of personality problems, even issues of national or world significance.

Typically, the success of economic reforms is associated with the containment of inflation, the prevention and elimination of risks, updating, modernization of technologies, fundamental changes in the structure and the state functions, improvement of democratic principles of society, protection of human rights, etc. Most of these problems cannot be solved without a profound transformation that depends directly on the level of information culture, the knowledge culture, skills, ability to work in a team, the behavior of managers and employees, their level of talent and other qualities. Consequently, the question of information culture is fundamental, where the rules of the creation of an innovative society, the formation of a new type of person and a fundamentally new technological basis for their spiritual and social modernization are closely interconnected.

From a methodological point of view, information culture is an element of the science concept about management, which has a complex knowledge character in various branches of science, including economics. Mastering an information culture is a way of the person qualities universalizing, which leads a person to a real understanding of his mission, place and role in the processes of world-building.

Information culture contributes to the formation of a person's:

- competence in tasks definition that need to be solved in their life;

- skills of modern computer technology use and all attributes of informatization;

- skills of formal description of the given tasks, elementary knowledge about methods of economicmathematical modeling and forecasting;

- knowledge of simple algorithmic structures and the ability to apply this knowledge to compile algorithms for solving any economic and sociotechnical problems;

- ability to interpret correctly the results of solutions to practical problems with the help of intellectual capabilities enhancers and use these results in practice;

- knowledge of the legal security problems and use of information, databases and knowledge;

- knowledge about the safety of the integrated control systems operation in two directions: safety of personnel and information security;

- ability to develop oneself and work in a team.

So, this is the minimum amount that each person must possess to live and work normally in the third millennium.

Conclusions. Nowadays, the development of the spirituality and mentality of a person, generated by his important quality - the social interaction talent with which he is born and lives his life is becoming one of the most important elements of social development. Only the appropriate approach to the development and management will allow achieving the desired success for the individual and, accordingly, the organization where he works. It can be argued that talent management, taking into account the free and tactful use of information and computer-based communication technologies, is becoming a prerequisite for the effective operation of any organization, since managing talent means attracting and retaining the best employees, and effective use of their potential for corporate purposes.

The results of scientific and technological progress, the increase in the information volume, the need to master it for effective activity, managerial decision-making cause the need for a person to develop his information culture as a condition and features of a civilized organization of the economy and a person on the basis of production means, which consist of the labor intelligent tools and new information technologies. The basic requirements of information culture to the person and its principles allow to manage talent effectively, create a space for his development and effective use in everyday and work activity, especially in the conditions of the third millennium - the millennium of information and communication technologies and a person with non-standard thinking.

\section{References}

1. Gardner, G. (2007). Struktura razuma. Teoriya mnozhestvennogo intellekta. [Frames of Mind: the Theory of Multiple Intelligences]. Moscow: Williams [in Russian].

2. Gates, B. (2000). Biznes so skorostyu myisli [Business@ @ the Speed of Thought]. Moscow: EKSMO-
Література

1. Гарднер, Г. Структура разума. Теория множественного интеллекта / Г. Гарднер. М. : Вильямс, 2007. $-512 \mathrm{c}$.

2. Гейтс, Б. Бизнес со скоростью мысли: / Б. Гейтс. М. : ЭКСМО-Пресс, 2000. - 480 с. 


\section{МЕНЕДЖМЕНТ}

Press [in Russian].

3. Hryshchenko, I. M. (2007). Osoblyvosti transformatsiinykh zmin $v$ ekonomitsi Ukrainy. [Features of transformational changes in the economy of Ukraine]. Pidpryiemnytstvo, hospodarstvo i pravo - Entrepreneurship, Management and Law, 3, 149-152 [in Ukrainian].

4. Moliako, V. O., Muzyka, O. L. (2006). Zdibnosti, tvorchist, obdarovanist: teoriia, metodyka, rezultaty doslidzhen [Ability, creativity, giftedness: theory, methodology, research results]. Zhytomyr: Ruta [in Ukrainian].

5. Chubukova, O. Y. (2017). Informatsiinyi marketynh [Informational marketing]. Kyiv: KNUTD [in Ukrainian].

6. Kalashnikova, S. A. (2010). Osvitnia paradyhma profesionalizatsii upravlinnia na zasadakh liderstva [Educational paradigm of management professionalization on the basis of leadership]. Kyiv: Kyiv university named after B. Hrinchenko [in Ukrainian].

7. Mayklz, E., Hendfild-Dzhons, H. \& Ekselrod, E. (2009). Voina za talanty [The War for Talent] (2nd ed.). Moscow: Mann, Ivanov i Ferber [in Russian].

8. Hryshchenko, I. M. (2014). Provedennia prohnoznoanalitychnykh doslidzhen vidpovidnosti systemy profesiinoi osvity perspektyvam sotsialno-ekonomichnoho-rozvytku Ukrainy [Carrying out of forecast-analytical researches on the correspondence of the system of vocational education to the prospects of socio-economic development of Ukraine]. Kyiv: KNUTD [in Ukrainian].

9. Reznikova, Zh. I. (2005). Intellekt i yazyik zhivotnyih $i$ cheloveka. Osnovyi kognitivnoy etiologii [Intellect and language of animals and humans. Fundamentals of Cognitive Etiology]. Moscow: Akademkniga [in Russian].

10. Schweyer, A. (2004). Talent Management Systems: Best Practices in Technology Solutions for Recruitment, Retention and Workforce Planning. Chichester: John Wiley \& Sons [in English].
3. Грищенко, І. М. Особливості трансфрормаційних змін в економіці України / І. М. Грищенко // Підприємництво, господарство і право. - 2007. - № 3. C. $149-152$.

4. Здібності, творчість, обдарованість: теорія, методика, результати досліджень / за ред. В. О. Моляко, О. Л. Музики. - Житомир : Рута, 2006. - 320 с.

5. Чубукова, О. Ю. Інформаційний маркетинг: навч. посібник / О. Ю. Чубукова. - К. : КНУТД, 2017- 112 с.

6. Калашнікова, С. А. Освітня парадигма профресіоналізації управління на засадах лідерства : монографія / С. А. Калашнікова. - К. : Київ. ун-т ім. Б. Грінченка, 2010. - 380 с.

7. Майклз, Э. Война за таланты / Э. Майклз, Х. Хэндфилд-Джонс, Э. Экселрод. - 2-е изд., М. : Манн, Иванов и Фербер, 2009. - 272 с.

8. Проведення прогнозно-аналітичних досліджень відповідності системи професійної освіти перспективам соціально-економічного розвитку України: монограффія / за заг. ред. І. М. Грищенка. - К. : КНУТД, 2014. - 350 с.

9. Резникова, Ж. И. Интеллект и язык животных и человека. Основы когнитивной этиологии / Ж. И. Резникова. - М. : Академкнига, 2005. - 518 с.

10. Schweyer, A. Talent Management Systems: Best Practices in Technology Solutions for Recruitment, Retention and Workforce Planning. John Wiley \& Sons, Chichester, Great Britain, 2004.

Бібліографічний опис для цитування :

Gryshchenko, I. M. Informatsiyna kultura yak osnova efektyvnoho upravlinnya talantom. [ Information culture as the basis of efficient talent management] / I. M. Gryshchenko, О. Y. Chubukova // Науковий вісник Полісся. - 2017. - № 4 (12). Ч. 2. C. 100-105. 